\title{
ENCOURAGEMENT OF PRO-ENVIRONMENTAL BEHAVIOUR (A CASE STUDY OF KYIV)
}

\author{
Olena KONONENKO
}

\author{
Taras Shevchenko National University of Kyiv, Ukraine \\ helen74@ukr.net
}

\begin{abstract}
Numerous theoretical frameworks have been dedicated to the problem of sustainable development of cities and regions. Although many practical actions have been undertaken, no perfect mechanism of encourage pro-environmental behaviour has been found yet.

Non-ecological behaviour is the most arduous barrier to achieving the sustainable development goals because of the various reasons such as low awareness of environmental issues, traditional values and lifestyle. Pro-environmental behaviours include such practices as recycling, electricity saving, water saving, using public transportation, bicycle or walking, using LED lamps instead of fluorescent lamps etc. The promotion of pro-environmental behaviours in people's daily lives is an important factor for stimulating the development of different sectors of green economy.

Our article describes a general assessment of the ecological behaviour of the population in the city of Kyiv and Ukraine as a whole. The regional features of pro-ecological behaviour, which are the differences in people's practices and attitudes in Western and Eastern parts of Ukraine, as well as in large cities and rural areas, are revealed. Also models of pro-environmental behaviour, which correspond to the sustainable development goals, have been distinguished. Formation of the model of behaviour depends on citizen's social status, age, education and other characteristics. The key element of the sustainable development mechanism is considered as a way of changing of behavioural patterns under the influence of certain tools that can be promoted by the city authorities.

The most effective way to encourage pro-environmental behaviour is combination of informational and structural strategies. The task of informational strategies is increasing actor's knowledge about behaviours. Structural strategies are aimed to change contextual factors such as the availability and the actual costs and benefits of behavioural alternatives. For implementation of encouraging policy is necessary to make a choice between a large number of measures and instruments of influence. We propose the individualized social marketing approach, in which interventions is tailored to the needs, wants and perceived barriers of individual segments of the city residents.

Key words: pro-environmental behaviour, sustainable development, sustainable consumption, environmental awareness, territorial community of the city.
\end{abstract}

DOI: https://doi.org/10.17721/2413-7154/2018.79.4-13

UDC: $911.3: 316.62$

Received: March 07, 2018.

Revised: May 12, 2018.

Accepted: May 17, 2018.

\section{МЕХАНІЗМИ ВДОСКОНАЛЕННЯ ЕКОЛОГІЧНОЇ ПОВЕДІНКИ НАСЕЛЕННЯ (НА ПРИКЛАДІ МІСТА КИЕВА)}

\author{
Олена КОНОНЕНКО \\ Київський начіональний університет імені Тараса Шевченка, Україна \\ helen74@ukr.net
}

Анотація: Значна кількість наукових праць присвячена проблемі реалізації ідей сталого розвитку на рівні регіонів і міст. Не зважаючи на те, що накопичено певний досвід та узагальнено основні ідеї, поки що немає відпрацьованого механізму зміни моделей поведінки населення відповідно до цілей сталого розвитку.

Неекологічна поведінка населення $є$ однією з найбільших перешкод на шляху досягнення цілей сталого розвитку, що спричинено недостатністю обізнаності населення щодо екологічних проблем, незмінністю традицій та стилю життя. Екологічна поведінка включає в себе такі практики як переробка сміття, зменшення споживання води та електричної енергії, використання громадського та вело транспорту, світлодіодних ламп замість флуоресцентнихта ін. Стимулювання екологічної поведінки у повсякденному житті населення $\epsilon$ важливим чинником розвитку зелених секторів економіки.

В статті дано загальну оцінку екологічній поведінці населення в місті Києві та Україні в цілому. Також виділені моделі поведінки населення залежно від її відповідності цілям сталого розвитку. Модель поведінки формується залежно від належності громадян до певних соціальних груп, їх віку, освіти та інших характеристик. В статті запропоновано як ключовий елемент механізму сталого розвитку розглядати зміну моделей поведінки населення під впливом певних засобів та інструментів, що можуть буди запроваджені міською владою.

Поєднання інформаційних та структурних стратегій $\epsilon$ найефективнішим способом стимулювання екологічної поведінки населення. Інформаційні стратегії мають на меті збільшення знань суб'єктів дії про види екологічної поведінки. Структурні стратегії спрямовані на зміну ситуативних чинників як, наприклад, наявність, фактичні витрати та переваги альтернативних видів поведінки. Реалізація політики заохочення потребує вибору між великою кількістю заходів та інструментів впливу. Ми пропонуємо індивідуалізований маркетинговий підхід, в якому заходи адаптуються до потреб, бажань та сприйняття бар'єрів екологічної поведінки окремими групами громадян.

Ключові слова: екологічна поведінка, сталий розвиток, стале споживання, екологічна свідомість, територіальна громада міста. 
Вступ. Сталий розвиток як світоглядна концепція передбачає здійснення глибинних трансформацій в усіх сферах людського життя, а індикатори сталого розвитку мають стати ключовими при формуванні національної та регіональних стратегій. В Україні процес зміни парадигми розвитку тільки розпочинається і тому актуальним $\epsilon$ завдання наукового обгрунтування напрямів і механізмів сталого розвитку на різних ієрархічних рівнях та визначення місця i ролі основних стейкхолдерів даного процесу.

Участь громадськості у вирішенні актуальних проблем суспільного розвитку має мультиплікативний ефект як для розвитку регіонів та населених пунктів, так і суспільства в цілому, оскільки сприяє більш ефективному використанню ресурсів, забезпечує інклюзивність розвитку та формування громадянського суспільства.

В контексті євроінтеграційного процесу та адаптації для України Цілей сталого розвитку до 2030 року [24], перегляду потребує ряд стратегічних документів та, відповідно, секторальних політик. В той же час, декілька важливих напрямів та механізмів $\epsilon$ недостатньо розвинутими, що може вплинути на результати реалізації політики сталого розвитку в цілому. Серед інших, це механізм залучення населення та окремих громадян до формування напрямів і механізмів сталого розвитку, а також до процесів реалізації окремих заходів.

Механізм забезпечення сталого розвитку розглядається як сукупність взаємопов'язаних елементів - принципів, теорій і концепцій, цілей, завдань, технологій, методів, інструментів їх реалізації, що органічно поєднуються в процесі здійснення послідовних дій органів публічної влади 3 метою забезпечення інтересів територіальної громади 3 урахуванням потреб прийдешніх поколінь [9, с. 17]. Складові відповідного механізму мають бути узгоджені ієрархічно (з глобальними та національними стратегіями та планами дій) та секторально (забезпечувати сталий розвиток промисловості, аграрної сфери, житловокомунального господарства, транспорту тощо).

Наукових розробок щодо вивчення можливостей залучення громадськості до вирішення завдань сталого розвитку проводиться недостатньо внаслідок міждисциплінарності такого роду досліджень та низького запиту, що лише в останні декілька років став зростати 3 активізацією практичної реалізації ідей сталого розвитку в Україні. 3 поміж досліджень вітчизняних вчених слід згадати національну доповідь «Соціально-економічний потенціал сталого розвитку України та і1ї регіонів», в якій розкрито духовно-культурний потенціал сталого розвитку регіону та розроблено його нормативну модель [20, с. 137]. Також через розкриття сутності духовного стану населення України автори монографії «Наукові засади розробки стратегії сталого розвитку України» бачать можливості для забезпечення переходу на модель сталого розвитку

(C) Olena Kononenko на рівні громад та окремих громадян [18, с. 148149]. Найвпливовішими чинниками необхідних змін $€$ сімейні традиції, громадські відносини, звичаї, мова, система освіти і виховання, сакральні цінності. Загальні тенденції щодо галузевих та просторових трансформацій в контексті переходу України на модель сталого розвитку висвітлені у монографічному дослідженні [22]. Автори наголошують на безперспективності слідуванню західній моделі «суспільства загального споживання [22, с. 95] та виявляють основні перешкоди, що стоять на шляху розвитку сталого споживання та виробництва.

Дослідження сталого розвитку територіальної громади [21] проведено 3 точки зору формування індивідуальної та колективної ідентичності та впливу лібералізму на формування цінностей та пріоритетів сталого розвитку. Автори розкривають окремі механізми та інструменти стимулювання сталого розвитку громади без окремого фокусування на проблемі залучення населення до екологічної поведінки та ресурсоощадних практик.

Метою даного дослідження $є$ характеристика екологічної поведінки населення та здійснення спроби виявлення і1і моделей на прикладі міста Києва, а також розроблення напрямів і механізмів вдосконалення міської екологічної політики, що грунтуються на важелях впливу на існуючі моделі поведінки з урахуванням цілей сталого розвитку.

Теоретичні основи дослідження. Однією 3 цілей сталого розвитку $\epsilon$ перехід до сталого споживання, тобто використання продукції та послуг, які забезпечують вищий рівень життя за одночасної мінімізації використання природних ресурсів та токсичних матеріалів, утворення відходів і забруднюючих речовин впродовж усього циклу виробництва і споживання продукції або послуги [25, с. 9]. Презентована Урядом України система цілей i завдань сталого розвитку на період до 2030 року містить операційні цілі 4.3. «Зробити міста та населені пункти інклюзивними, безпечними, життєстійкими та збалансованими» та 5.1. «Забезпечити перехід до моделей збалансованого споживання та виробництва» [24], які безпосередньо пов'язані з більш активним залученням населення до вирішення екологічних проблем міст та загалом фундаментальною зміною підходів до природокористування, споживання товарів і послуг, стилю життя населення. Стосовно особливостей життєдіяльності населення, стале споживання (sustainable consumption) означає зміни в обсягах споживання товарів і послуг (наприклад, зменшення споживання води, електричної енергії, палива та ін.), а також структури споживання (надання переваги пішим прогулянкам та використання громадського транспорту перед використанням легкового автомобіля). В окремих випадках можливе зменшення споживання та одночасне збереження якості отримуваних благ (наприклад, використовуючи енергоефективні лампи замість ламп розжарювання), але загалом існує пряма залежність між рівнем життя населення та ступенем його впливу на довкілля. Це досліджено за допомогою показника екологічного 
сліду: найбільший екологічний слід мають США, Канада, Австралія, які також мають високий рівень розвитку економіки, людського розвитку, освіти, охорони здоров'я тощо [17, с. 4751]. Країни з середнім та низьким рівнем соціально-економічного розвитку мають суттєво менший екологічний слід, а значить, стрімко розвиваючи економіку, ці країни будуть наближатись до критично високих рівнів екологічного сліду, якщо не змінять при цьому модель споживання. Загроза такого розвитку подій існує і для України.

Загальна схема переходу від традиційної моделі споживання до такої, що відповідає принципам сталого розвитку, представлена на рис. 1. Такі поняття, як екологічна свідомость (environmental awareness), ставлення до навколишнього середовища (environmental attitude), екологічна поведінка (proenvironmental behaviour), екологічне громадянство (environmental/green citizenship) можна розглядати двояко: як складові сталого споживання, оскільки останнє є більш широким поняттям, і як механізм переходу від традиційного до сталого споживання.

Окремі поняття мають причинно-наслідковий зв'язок: для розширення проявів екологічної поведінки (екологічних та ресурсоощадних практик) необхідна достатня кількість достовірної екологічної інформації, що сприяє формуванню відповідного ставлення до навколишнього середовища. Також високий рівень поінформованості сприяє формуванню екологічного громадянського суспільства.

Розроблення механізму зміни моделей поведінки потребує вивчення чинників екологічної поведінки. У попередньому дослідженні [12] було проаналізовано групи чинників відповідно до праць Л. Хюнсук (L. Hyunsook), К. Курісу (K. Kurisu), К. Ханакі (К. Hanaki), Х. Лі (H. Lee), А. Колмус (A. Kollmuss) [10-11, 13-14]. Більшість вчених схиляються до думки, що на поведінку населення впливають одразу декілька факторів 3 таких основних груп: психологічні чинники, матеріальний зиск i вигоди, знання, соціально-демографічні чинники (стать, вік, рівень освіти, рівень доходів), особистісні та ситуативні.

Кількість факторів, що визначають ступінь екологічності поведінки населення постійно зростає: в ранній моделі раціональної поведінки, розробленій Дж. Берджессом (J. Burgess) [5], основним чинником було визначено екологічні знання та інформацію, але 3 часом поведінкові моделі ускладнювались, i Й. Тогерсен (J. Thøgersen) додатково розглянув i обгрунтував чинники моралі [26], I. Айзен (I. Ajzen) матеріального зиску [3], С. Х. Шварц (S. H. Schwartz) та Дж. А. Говард (J. А. Howard) - соціальних норм [19], М. Аоягі-Усуї (М. Aoyagi-Usui), Х. Вінкен (H. Vinken), А. Курібаясі (A. Kuribayashi) - ситуативні, національних традицій [4] та інші.

Серед моделей і теорій екологічної поведінки, що побудовані на домінуванні одного ключового чи декількох факторів, цікавою видається теорія структурування цілей (goal-framing theory) обгрунтована С. Лінденбергом (S. Lindenberg), Л. Стег (L. Steg) [16]. Вона передбачає існування трьох ключових цілей, що визначають поведінку людини: гедонічної, що спрямована на забезпечення максимальної комфортності індивіда в конкретний момент часу, прагматичної, що спрямована на отримання матеріальної користі та збереження ресурсів та нормативної, що спонукає індивіда діяти відповідно норм і правил, що склались в суспільстві. Прийняття рішення щодо вибору тієї чи іншої моделі поведінки залежить від того, яка ціль є домінуючою на даний момент (іншими словами, знаходиться в фокусі). Інші цілі при цьому враховуються, але в значно меншій мірі. Відповідно до даної теорії, спонукання людини діяти більш екологічно можна забезпечити за допомогою принаймні трьох механізмів:

- створюючи матеріальні стимули або санкції

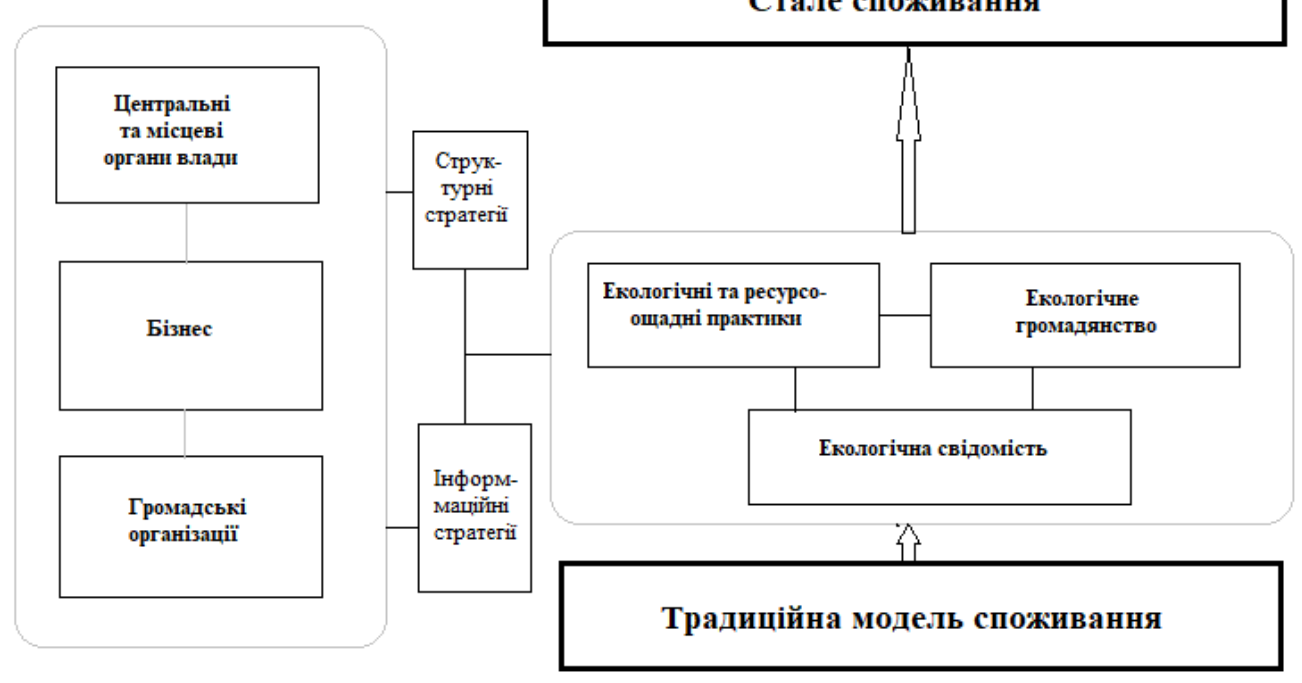

Рис. 1. Загальна схема переходу від традиційної до сталої моделі споживання (розроблено автором) 
у вигляді гнучкої цінової, податкової політики, штрафів, митних пільг тощо - ці дії спрямовані на посилення прагматичної цілі;

- спрощуючи доступ населення до закладів інфраструктури, що полегшують екологічні дії, роблять їх менш праце- i часомісткими - ці дії спрямовані на посилення гедонічної цілі;

- формуючи наочні приклади доцільної екологічної поведінки, заохочуючи при цьому наслідувати приклад; це може посилити нормативну ціль та сприяти формуванню нових моделей поведінки та традицій, які вчені вважають досить стійкими, тобто такими, що визначають екологічність поведінки декількох поколінь населення [4].

Відповідно до теорії структурування цілей, важливо стимулювати досягнення всіх цілей, оскільки вони посилюють одна одну. Працюючи тільки в одному напрямі - наприклад, розвинувши інфраструктуру, але при цьому не забезпечивши необхідних матеріальних стимулів - в результаті можна отримати дуже невелике зростання частки населення, що даною інфраструктурою користується. Хоча дуже важко передбачити, яка ціль буде домінувати у конкретного індивіда в певний момент часу, та все ж певні цілі $є$ «сильнішими», тобто впливають на дії людини більше. Так, за існування рівної кількості аргументів «за» і «проти» екологічної поведінки гедонічні цілі частіше беруть верх [13, c. 122] i індивід вчиняє не екологічно, оскільки екологічно спрямована поведінка, як правило, потребує додаткових зусиль.

Розвинені країни світу мають певний досвід стимулювання екологічно спрямованої поведінки населення, що базується на перевірених та універсальних методах регіональної економічної та соціальної політики: ціновому регулюванні, податках, штрафах тощо [7, с. 277]. Часто політика держави щодо екологічної сфери грунтується на потужній інформаційній кампанії, що відповідає моделі раціональної поведінки: наприклад, програми уряду Великобританії [15, с. 17]. В цілому, є наступні стратегії щодо підвищення рівня екологічної активності населення: 1) первинна (упереджуюча) передбачає інформування населення щодо можливих наслідків застосування певних моделей поведінки; 2) наслідкова (результуюча) - спрямована на зміну факторів, що визначають поведінку населення, може бути як стимулюючою, заохочувальною реакцією на дії населення, так і караючою за нанесення суттєвої шкоди навколишньому середовищу.

За своєю суттю стратегії поділяють на дві групи: інформаційні та структурні. Найбільше обговорюваними в науковій літературі $€$ інформаційні, оскільки $є$ питання щодо їх ефективності: обізнаність населення не обов'язково призводить до екологічної поведінки та зміни моделей споживання [6]. На прикладі застосування більш енергоефективних моделей споживання B. Абрахамс (W. Abrahamse) та ін. [2, с. 278] доводять, що інформаційні стратегії $\epsilon$ обов'язковою, але недостатньою складовою політики сталого розвитку. Їх ефективність суттєво зростає, якщо поширювати не тільки інформацію про можливі екологічні дії, шкоду для навколишнього середовища, але певні моделі поведінки, кейси, що демонструють їх зручність та ефективність. Загалом, інформаційні стратегії більш ефективні щодо екологічної поведінки, яка не потребує значних зусиль та коштів.

Структурні стратегії включають широкий спектр заходів, що створюють стимули, штрафи i систему покарань у сфері використання природних ресурсів та екології. Набір заходів сильно залежить від виду бажаної екологічної поведінки. Наприклад, для зростання частки сміття, що здається на переробку, суттєвою є інфраструктура (спеціальні сміттєві баки, пункти прийому) [15, с. 20-21]. Загалом, структурні стратегії є більш ефективними, ніж інформаційні [23, с. 314], оскільки часто використовуються щодо поведінки населення, що здійснює суттєвий вплив на навколишнє середовище - споживання палива i енергії, поводження зі сміттям, купівля екологічно безпечних товарів тощо. Слід зазначити, що населення краще сприймає заходи не заборонного, а стимулюючого або обмежувального характеру.

Очевидно, що існуючі моделі споживання населення є непростим об'єктом для управління через існування часового розриву між діями населення та їх кінцевим результатом покращенням стану навколишнього середовища. Існування саме цієї складності робить регіональний та місцевий рівень більш ефективним, ніж вищі рівні управління. Успішне вирішення однієї чи декількох екологічних проблем місцевого значення сприяє мотивації населення та підвищує комфортність умов проживання, що стимулює гедонічні цілі.

Підвищити результати регіональної екологічної політики щодо формування сталих моделей споживання можна, якщо розглядати територіальну громаду не як єдиний та однорідний об'єкт впливу, а як структурований за ознакою схильності до змін у щоденних моделях поведінки. Ця теза грунтується на дослідженнях, що доводять схильність, наприклад, жінок та молоді до більш активної про екологічної позиції. Також виявлено ознаки того, що рівень освіти, тривалість проживання в регіоні, майновий стан домогосподарств впливають на екологічність поведінки населення [11, с. 248-253]. Спираючись на розробки та досвід Великобританії [8], ми вважаємо ефективним виділяти в територіальній громаді групи мешканців, що відрізняються за ступенем залучення до екологічної поведінки, виявляти їх характерні риси відповідно до суттєвих ознак (вік, стать, рівень освіти тощо) та здійснювати цільовий вплив на відповідні групи, що може дати більший ефект порівняно з єдиною політикою по відношенню до всього населення регіону.

Групування населення відповідно його готовності до екологічної діяльності та поширеності екологічних та ресурсоощадних практик. У даному дослідженні представлено спробу виділити групи населення в територіальній громаді м. Києва, для кожної $з$ яких характерний 
певний тип (модель) поведінки в екологічній сфері. Дані групи відрізняються принаймні двома характеристиками: ступенем готовності діяти та залученістю до конкретних дій. На відміну від дослідження, що було проведено у Великобританії [8], дане групування дозволило виділити не сім, а п’ять груп, що обумовлюється невисоким рівнем обізнаності та активності населення в даній сфері та малочисельністю груп. Групування проведено за результатами опрацювання 229 анкет, що були заповнені у червні 2016 року в різних частинах міста Києва: в центральній частині міста на вул. Басейній, на лівому березі поблизу вулиць Лєбєдєва та Азейбарджанська, а також на вулицях Глибочицька та Івана Кудрі. Співвідношення чоловіків та жінок склало $45 \%$ та 55\% відповідно, вікова структура опитаних наступна: $18-24$ р. $13,5 \%$; 25-34 p. 32,3\%; $35-60$ p. 38,4\%; старше 60 р. - 15,8\%. Запитання щодо екологічної поведінки та ресурсоощадних практик (табл. 1) були поставлені в рамках дослідження НДЛ «Регіональних проблем економіки та політики» географічного факультету КНУ імені Tараса Шевченка сприйняття жителями Києва просторових трансформацій.

Загалом, для міських поселень України характерна більша схильність до екологічно свідомої поведінки та застосування ресурсоощадних практик у порівнянні 3 сільською місцевістю. Так, 6,8\% міських жителів не готові до щоденної екологічної поведінки, а серед мешканців сільської місцевості частка цієї групи населення склала $10 \%$ [27, с. 32]. Щодо міста Києва, то у порівнянні 3 іншими регіонами країни можна говорити про найбільший рівень готовності та залучення населення до про екологічної поведінки: найменша частка населення серед всіх регіонів України висловила свою неготовність до такого роду практик $(3,3 \%)$, більше половини населення має бажання діяти і 45,6\% населення мають досвід екологічної поведінки. Такі регіональні особливості обумовлені рядом причин: найбільш сприятливою віковою структурою населення, освітнім рівнем, а також чинником столичності. Столичність у даному контексті виявляється у більш швидкому сприйнятті інновацій, в тому числі i моделей поведінки населення, що характерні для країн Європи та Північної Америки та відзначаються високим рівнем соціального залучення та екологічною спрямованістю.

Щодо видів екологічних практик, жителі міста Києва в найбільшій мірі готові до сортування сміття та здавання його на переробку (72,9\%) i інших дій, пов'язаних з чистою та охайністю місць проживання (див.табл. 1), що є загальноукраїнською тенденцією i підтверджується результатами опитування, згідно якого прибирання території $\epsilon$ найбільш поширеною екологічною практикою і охоплює 62,1\% населення [27, с. 51]. До зміни моделей поведінки у сфері транспорту населення в більшій мірі не готове, оскільки свідома відмова від використання власного авто на користь більш екологічних способів пересування складає приблизно 30\%, а частка населення, що практикує - це близько 12-13\% залежно від альтернативного способу пересування.

Загалом, розриви між бажанням діяти i практиками складають 2 рази, що близьке до результатів всеукраїнського опитування $55, \%$ i 35,6\%. При цьому слід зазначити що у останньому випадку враховувались не тільки «чисті» екологічні дії (які громадянин здійснює свідомо і у відповідності 3 своїми екологічними переконаннями), а і ресурсоощадні, що здійснюються 3 метою економії коштів домогосподарств (економія тепла, електричної енергії, води тощо внаслідок їх суттєвого здороження останніми роками).

Головне завдання групування - виявити групи населення, що мають близькі патерни поведінки не фокусуючись при цьому на розмірах груп, які можуть бути різними, оскільки у даній сфері відбуваються суттєві трансформації і поведінка населення залежить не тільки об'єктивних i передбачуваних чинників, але також від ситуативних, випадкових. Визначаючи групи ми вважали за доцільне орієнтуватись на модель екологічної сегментації (Defra's environmental segmentation model), розроблену на замовлення Департаменту екології, продовольства та

Висловлена респондентами готовність до екологічної діяльності

Таблицяя 1 та їх практичні дії

\begin{tabular}{|l|c|c|}
\hline \multicolumn{1}{|c|}{ Екологічні практики населення } & Бажання діяти (\%) & Практичні дії (\%) \\
\hline Здавання на переробку упаковки, батарейок, сортування сміття & 72,9 & 32,7 \\
\hline $\begin{array}{l}\text { Використання для переміщення по місту велосипеду або піших } \\
\text { прогулянок }\end{array}$ & 28,4 & 13,5 \\
\hline Використання для поїздок по місту громадського транспорту & 34,1 & 12,7 \\
\hline Прибирання за домашніми улюбленцями & 31,9 & 8,3 \\
\hline Участь у заходах з прибирання та озеленення міста & 31,9 & 11,4 \\
\hline $\begin{array}{l}\text { Ставлення до введення штрафів за викидання сміття на вулицю, } \\
\text { матеріальна підтримка природоохоронних заходів }\end{array}$ & 41 & 5,3 \\
\hline Ніякі з перерахованих & 3,5 & 49,3 \\
\hline
\end{tabular}




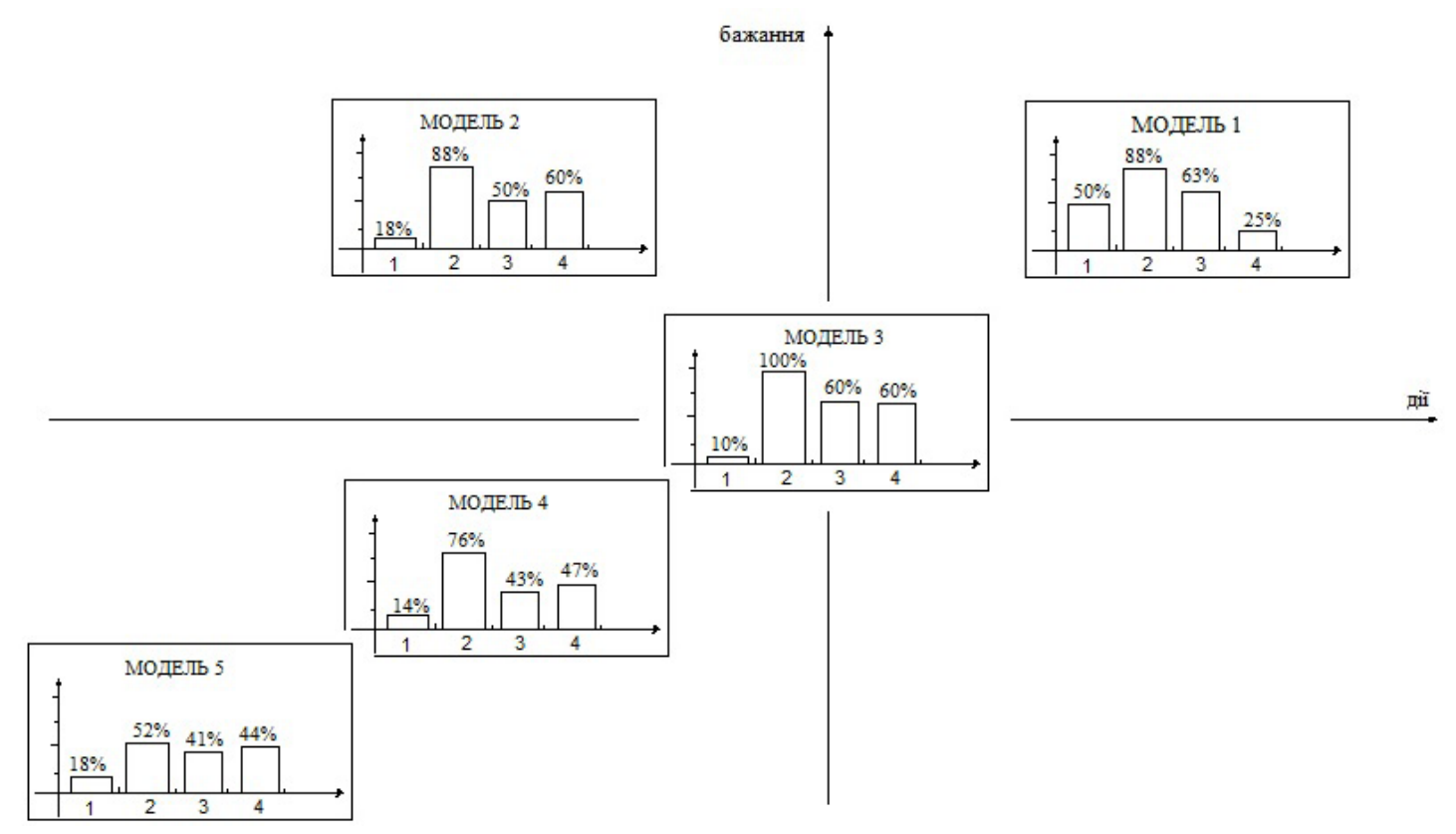

Рис. 2. Моделі поведінки населення Києва залежно від їх відповідності цілям сталого розвитку (розроблено автором)

сільського господарства Уряду Великобританії [8], максимально враховуючи місцеву специфіку. Оскільки групи виділялись за двома ключовими ознаками, то візуальне їх представлення найбільш логічне на тлі системи координат (рис. 2) де абсциса відповідає бажанню громадян діяти екологічно, а ордината - інтенсивності таких дій.

Для кожної 3 виділених моделей поведінки на схемі подано характеристики групи: частка населення, що проживає в місті менше 5 років, \% (1), частка населення 3 вищою освітою (2), частка населення молодше 35 років, \% (3), частка населення, що має доходи більше 5 тис. грн. (4). Дані характеристики найбільш варіюють залежно від групи, в той час як стать, сфера зайнятості та рід занять не здійснили суттєвого впливу на належність окремого громадянина до тієї чи іншої групи.

Модель 1 - модель сформованої екологічно орієнтованої поведінки. Характерна для громадян, чиї екологічно орієнтовані практики грунтуються на знаннях та переконаннях. До цієї найменш чисельної групи (3,6\% опитаних) нами віднесено респондентів, що відзначили понад чотири діiі, що бажають виконувати та при цьому мають досвід у більш ніж трьох екологічних практиках. Доцільність виділення даної групи обумовлена наступними міркуваннями. По-перше, це є певний «репер», на який можна буде орієнтуватись у майбутньому при проведенні часових зрізів щодо динаміки формування про екологічної поведінки населення. Ми прогнозуємо що ця група буде досить суттєво зростати за рахунок зменшення часток інших груп. Другий аргумент пов'язаний 3 важливим значенням цієї групи, яка може взяти на себе функцію лідера, ініціатора змін на місцевому рівні. Способи залучення активних громадян можуть бути різні - робота в громадських організаціях, ініціювання проектів та акцій, здійснення екологічного контролю, екологічна освіта тощо. При цьому найбільш суспільно значимим є не стільки ефект щодо покращення стану навколишнього середовища, як поширення у суспільстві позитивного досвіду, що має з часом закріпитись як нова норма поведінки.

Дана група об’єднує людей молодого і середнього віку, що мають вищу освіту. Всі представники групи підтримують введення штрафів за викидання сміття на вулицю, переважна більшість (75\%) безпосередньо беруть участь в озелененні та благоустрої міста. Те, що до цієї групи не увійшли громадяни з високим рівнем доходів, свідчить про альтруїстичність їх поведінки, що розглядається ними самими не як «хобі», а як суспільно значима дія.

Модель 2 - модель 3 чітко вираженими екологічними намірами та низьким рівнем практичної участі. Дана група громадян об’єднує 14,9\% опитаних. Їх можна розглядати як потенційно активних, дії яких однак стримуються внаслідок певних причин. За бажанням діяти респонденти настільки ж зацікавлені, як і представники першої групи (більше 4 практик), але їх активність обмежується максимум двома видами активності. Група об'єднує людей молодого i зрілого віку, характеризується високим рівнем освіти, доходів, висока частка людей, що нещодавно в місті. Висока частка молоді у групі свідчить загалом на 111 готовність змінювати модель поведінки та існування запиту на місцеві ініціативи, програми, гранти для молоді, які були б спрямовані на отримання корисних порад, навичок або отримання можливості діяти спільно та вирішувати нагальні екологічні проблеми міста.

Модель 3 - модель зі усталеними окремими ресурсоощадними практиками та помірною екологічною активністю. Дану невелику групу (4,5\% опитаних) формують прагматично настроєні громадяни, що мають досвід дій у екологічній сфері, але які не висловили бажання розширювати спектр 
своєї діяльності. Цілеспрямована робота 3 даною групою має передбачати не стільки заохочення до дій, скільки збільшення розуміння 3 якою метою проводиться подібна політика, якими $є$ коротко i довгострокові їі наслідки.

Група характеризується відсутністю людей пенсійного віку, має високий рівень освіти, об'єднує людей, що переїхали до Києва приблизно 10 років тому, серед напрямів екологоорієнтованої поведінки всі вказали сортування сміття. Дану групу слід вважати драйвером механізму сталого розвитку громади, оскільки саме іï представники швидко опановують практичні навички.

Модель 4 - модель низького рівня бажання та реалізації екологічно орієнтованої поведінки. Це найбільш чисельна група населення (45,9\% населення), що вказала менше 4 позицій екологічних дій, які можуть бути для неї цікавими, та має практичний досвід менш, ніж по двох. Основною ознакою, що об'єднує людей у групу 4 $€$ досить тривалий час проживання в місті Києві (в середньому 20 років). Громадяни мають усталений ритм життя, середній рівень доходів та достатньо високий рівень освіти (76\% опитаних зазначили, що мають вищу освіту) i не бачать суттєвих причин для його зміни. Через свою чисельність дана група потребує значної уваги при запровадженні механізму сталого розвитку. При цьому доцільно використовувати як інформаційні, так і структурні стратегіï, намагаючись задіяти всі види цілей (прагматичні, гедонічні та нормативні). 3 високою імовірністю запровадження нових норм поведінки у екологічній сфері для цієї групи може виявитись дієвим, особливо якщо ці норми будуть поширюватись традиційними каналами отримання інформації: телебачення, преса, будинкові, квартальні комітети, ОСББ тощо.

Модель 5 - модель високого рівня відторгнення від екологічних та ресурсоощадних практик. Дана група об'єднує 31,1\% опитаних та відзначається незалученістю до екологічно орієнтованих практик у будь-якій формі і при цьому рівень бажання діяти також вкрай низький (2 і менше позиції в анкеті). Група виділяється порівняно низьким рівнем освіти, найбільш тривалим періодом проживання в місті (в середньому - 23 роки), відчутною є частка населення с середніми та низькими доходами.

Для найбільш пасивної в плані екологічної діяльності групи перспективним $є$ запровадження ресурсоощадних практик, оскільки вони дають можливість суттєво зменшити витрати домогосподарств, а також i екологічний слід та негативні наслідки для навколишнього середовища. Недоцільно намагатись радикально зменшити чисельність даної групи у міській громаді, оскільки до неї відносяться також громадяни зі слабкою соціальною та політичною позицією загалом, представництво яких є у будь-якому суспільстві.

Формування механізму сталого розвитку територіальної громади. Інструменти та механізми, що покликані змінити традиційні моделі природокористування, мають бути різними для різних ієрархічних рівнів управління, але мати при цьому спільний вектор та бути узгодженими у часовому, галузевому та територіальному аспектах. Фінансові стимули та санкції, як правило, запроваджуються на регіональному або національному рівнях 3 урахуванням вже існуючого податкового навантаження, а також додаткових витрат, пов'язаних 3 адмініструванням податків, здійсненням контролю та нагляду. Також на національному рівні мають бути визначені умови ведення бізнесу у зелених секторах економіки: зеленої енергетики, туризму, сільського господарства.

На муніципальному рівні механізми сталого розвитку мають бути безпосередньо пов'язані 3 екологічним громадянством, що покликане узгодити невідповідності між задоволенням особистих потреб громадян та потреб громади, що проживає на конкретній території [7, с. 281-282]. Як зазначає А. Добсон (A. Dobson), екологічне громадянство $є$ механізмом зміни існуючих цінностей на користь суспільних та також інтересів прийдешніх поколінь. Загалом, більшість теоретиків та практиків сходяться на думці, що механізми безпосереднього залучення громадян до екологічних дій та ресурсоощадних практик $\epsilon$ більш ефективними порівняно 3 фіскальними методами, оскільки вони є початком діалогу між основними стейкхолдерами процесу: місцевою i центральною владою, громадськими організаціями різного спрямування [1, с. 11-12].

Аналіз ефективності окремих екологічних ініціатив [1, с. 18-35] показав, що на місцевому рівні можуть використовуватись заходи щодо інформування населення про екологічні проблеми та можливі шляхи їх вирішення, проекти, що передбачають апробацію окремих екологічних ініціатив i практик у організаціях та домогосподарствах (наприклад, до сортування та переробки сміття, зменшення використання електричної енергіi), використання партисипативних бюджетів для реалізації екологічних проектів, підтримка місцевих громадських екологічних організацій, волонтерського руху тощо. Міська влада має можливості підтримувати і розвивати екологічну освіту на різних рівнях, забезпечувати доступ до центрів надання екологічно спрямованих послуг, залучати населення до процесу складання стратегій і програм розвитку міста, генпланів.

Ми пропонуємо для виявлених моделей екологічної поведінки населення міста Києва застосовувати наступні методи та інструменти впливу:

1. Для моделей 1 i 2 розробити методи, що стимулюватимуть нормативні цілі екологічної поведінки, а саме поширення європейського i світового досвіду вирішення екологічних проблем міст, організація конкурсів екологічних проектів для активної молоді та молодіжних громадських організацій тощо.

2. Для моделі 3 використовувати методи, що стимулюватимуть прагматичні цілі, а саме 
запровадити гнучку систему штрафів і фінансових стимулів щодо вирішення таких гострих проблем, як поводження зі сміттям, благоустрій території, високий рівень забруднення повітря викидами пересувних джерел.

3. Для моделей 4 i 5 доцільно обрати методи та інструменти, що впливають на гедонічні цілі, а саме приділяти більше уваги програмам вдосконалення міської інфраструктури у сфері збирання та сортування сміття, роботи міського громадського транспорту, енергоефективності будівель тощо.

Висновки. Механізм сталого розвитку територіальної громади має будуватись на основі розуміння всіма зацікавленими суб'єктами існуючих загроз, цілей i завдань, а також передбачати узгодження дій. Як показало дослідження, населення міст недостатньо обізнане
3 проблемами сталого розвитку та майже не залучене до практично діяльності, що свідчить про низький рівень ефективності діючого механізму сталого розвитку в цілому.

Виявлені моделі поведінки населення міста Києва відрізняються між собою за рівнем активності у сфері охорони навколишнього середовища i ресурсозбереження. Механізм сталого розвитку має стимулювати збільшення частки громадян, поведінка яких близька до моделей 1-3 за рахунок зменшення частки громадян, поведінка яких близька до моделей 4 i 5. Адресний вплив на виділені групи населення може бути більш ефективним порівняно з єдиними методами і прийомами для всієї громади міста.

Періодичні дослідження екологічності поведінки населення міста у майбутньому дозволять оцінити ефективність діяльності міської влади та стати основою для майбутніх управлінських рішень.

\section{References:}

1. A review of best practice in environmental citizenship models. June, 2012, [Electronic source]. Access mode: http://www.epa.vic.gov.au/about-us/ /media/Files/about_us/EnvironmentalCitizenshipSynthesisFINAL14Sept12.pdf.

2. Abrahamse W., Steg L., Vlek C., Rothengatter J. A. A review of intervention studies aimed at household energy conservation. Journal of Environmental Psychology, 2005, 25, pp. 273-291.

3. Ajzen I. The theory of planned behavior. Organizational Behavior and Human Decision Processes, 1991, Vol. 50 (2), pp. 179-211.

4. Aoyagi-Usui M., Vinken H. and Kuribayashi A. Pro-environmental attitudes and behaviors: an international comparison. Human Ecology Review, 2003, Vol. 10, N. 1, pp. 23-31.

5. Burgess J., Harrison C., Filius P. Environmental communication and the cultural politics of environmental citizenship. Environment and Planning, 1998, Vol. 30, pp. 1445-1460.

6. Carmi N., Arnon S., Orion N. Transforming environmental knowledge into behavior: the mediating role of environmental emotions. Journal of Environmental Education, 2015, Vol. 46, I. 3, pp. 183-201.

7. Dobson A. Environmental Citizenship: Towards Sustainable Development. Sustainable Development, 2007, Vol. 15, pp. 276-285

8. Framework for pro-environmental behavior. Report for Department for Environment, Food and Rural Affairs. January 2008. [Electronic source]. Access mode: https://www.gov.uk/government/uploads/system/uploads/attachment_ data/file/69277/pb13574-behaviours-report-080110.pdf.

9. Gordêêv O. K. Mehanizmi zabezpečennâ stalogo rozvitku teritorial'nö̈ gromadi [Mechanisms of the sustainable development of the territorial community]. Odessa, 2014, 20 p. (In Ukrainian).

10. Hyunsook L. Influential factors on pro-environmental behaviors - a case study in Tokyo and Seoul. Low Carbon Economy, 2013, Vol. 4, pp. 104-116.

11. Kollmuss A. Mind the gap: why do people act environmentally and what are the barriers to pro-environmental behavior? Environmental Education Research, 2002, Vol. 8, No. 3, pp. 239-260.

12. Kononenko O. Proekologǐčna povedìnka naselennâ âk ob'êkt suspìl'no-geografǐčnih doslìdžen' [Proenvironmental behaviors as an object of human geography studies]. Časopis kartografï [Magazine of cartography], 2016, Vol. 16, pp. 145-156. (In Ukrainian).

13. Kurisu K. Pro-environmental Behaviors. Tokyo, Heidelberg, New York, Dordrecht and London: Springer, 2015.

14. Lee H., Kurisu K., Hanaki K. The Effect of Information Provision on Pro-Environmental Behaviors. Low Carbon Economy, 2015, Vol. 6, pp. 30-40.

15. Lehman Philip K., Geller E. Scott. Behavior analysis and environmental protection: accomplishments and potential for more. Behavior and Social Issues, 2004, Vol. 13, pp. 13-32.

16. Lindenberg S., Steg L. Normative, gain and hedonic goal frames guiding environmental behavior. Journal of Social Issues, 2007, Vol. 63 (1), pp. 117-137.

17. Moore J. Ecological Footprints and Lifestyle Archetypes: Exploring Dimensions of Consumption and the Transformation Needed to Achieve Urban Sustainability. Sustainability, 2015, Vol. 7, pp. 4747-4763.

18. Naukovi zasadi rozrobki strategï stalogo rozvitku Ukrä̈ni [Scientific bases of development of the Sustainable Development Strategy for Ukraine]. Odessa: Institute for Market Issues and Economic and Environmental Research of the National Academy of Sciences of Ukraine, 2012, 714 p. (In Ukrainian).

19. Schwartz S. H., Howard J. A. A normative decision-making model of altruism. In: Altruism and helping behaviour: Social, personality and developmental perspectives. Eds.: J. Philippe Rushton, Richard M. Sorrentino. Mahwah, NJ: Lawrence Erlbaum Associates, 1981, pp. 189-211. 
20. Socìal'no-ekonomičnij potencìal stalogo rozvitku Ukraïni ta ïi regìonìv: nacìonal'na dopovìd' [Socio-economic potential of sustainable development of Ukraine and its regions: national report]. (Eds.: Libanova E., Khvesyk M. Kyiv, State Institution "Institute of Environmental Economics and Sustainable Development of the National Academy of Science of Ukraine", 2014, 776 p. (In Ukrainian).

21. Stalij rozvitok teritorial'noï gromadi: upravlins'kij aspekt [Sustainable development of the territorial community: the administrative aspect]. Eds.: Kuts Y., Mamonova V. Kharkiv, Kharkiv Regional Institute of Public Administration, Mahistr, 2008, 236 p. (In Ukrainian).

22. Stan vikonannâ v Ukraïni položen' "Porâdku dennogo na XXI stolittâ" (2002-2012) [The state of implementation of the principles of the "Agenda for the 21st Century" in Ukraine (2002-2012)]. Ed.: Rudenko L. Kyiv, Akademperiodyka, 2014, 359 p. (In Ukrainian).

23. Steg L., Vlek C. Encouraging pro-environmental behaviour: An integrative review and research agenda. Journal of Environmental Psychology, 2009, Vol. 29 (3), pp. 309-317.

24. Strategiâ stalogo rozvitku Ukraïni do 2030 roku. Proekt 2017. [Sustainable development strategy for Ukraine till 2030. Project of 2017]. [Electronic source]. Access mode: http://www.ua.undp.org/content/ukraine/uk/home/library/ sustainable-development-report/Sustainable-Dev-Strategy-for-Ukraine-by-2030.html (In Ukrainian).

25. Sustainable Consumption and Production Indicators for the future SDGs. UNEP Discussion Paper. March 2015. [Electronic source]. Access mode: https://sustainabledevelopment.un.org/content/documents/2301SCP\%20 indicators.pdf.

26. Thøgersen J. Recycling and morality. A critical review of the literature. Environment and Behavior, 1996, Vol. 28 (4), pp. 536-558.

27. Uâvlennâ naselennâ pro stalij rozvitok. Analitičnij zvìt za rezul'tatmi nacìonal'nogo socìologičnogo opituvannâ, Berezen' 2017 [Population's perception of sustainable development - An Analytical Report on the Results of a National Sociological Survey, March 2017]. [Electronic source]. Access mode: http://www.ua.undp.org/content/ukraine/uk/ home/library/democratic_governance/report_population_perception_sustainable_development.html. (In Ukrainian).

\section{Список використаних джерел:}

1. A review of best practice in environmental citizenship models. June, 2012, [Electronic source] // Environment Protection Authority Victoria [web-site]. - Access mode: http://www.epa.vic.gov.au/about-us/ /media/Files/about_us/ EnvironmentalCitizenshipSynthesisFINAL14Sept12.pdf.

2. Abrahamse W. A review of intervention studies aimed at household energy conservation / W. Abrahamse, L. Steg, C. Vlek, J. A. Rothengatter // Journal of Environmental Psychology. - 2005. - Vol. 25. - P. 273-291.

3. Ajzen I. The theory of planned behavior / I. Ajzen // Organizational behavior and human decision processes. - 1991. - Vol. 50 (2). - P. 179-211.

4. Aoyagi-Usui M. Pro-environmental attitudes and behaviors: an international comparison / M. Aoyagi-Usui, H. Vinken, A. Kuribayashi // Human Ecology Review. - 2003, - Vol. 10. - N. 1. - P. 23-31.

5. Burgess J. Environmental communication and the cultural politics of environmental citizenship / J. Burgess,

C. Harrison, P. Filius // Environment and Planning. - 1998. - Vol. 30. - P. 1445-1460.

6. Carmi N. Transforming environmental knowledge into behavior: the mediating role of environmental emotions

/ N. Carmi, S. Arnon, N. Orion // Journal of Environmental Education. - 2015. - Vol. 46. - I. 3. - P. 183-201.

7. Dobson A. Environmental Citizenship: Towards Sustainable Development / A. Dobson // Sustainable Development. - 2007. - Vol. 15. - P. 276-285.

8. Framework for pro-environmental behavior. - Report for Department for Environment, Food and Rural Affairs. January 2008. - [Electronic source]. - Access mode: https://www.gov.uk/government/uploads/system/uploads/ attachment_data/file/69277/pb13574-behaviours-report-080110.pdf.

9. Гордєєв О. К. Механізми забезпечення сталого розвитку територіальної громади / О. К. Гордєєв. Одеса, 2014. $-20 \mathrm{c}$.

10. Hyunsook L. Influential Factors on Pro-Environmental Behaviors - A Case Study in Tokyo and Seoul / L. Hyunsook // Low Carbon Economy. - 2013. - Vol. 4. - P. 104-116.

11. Kollmuss A. Mind the Gap: Why do people act environmentally and what are the barriers to pro-environmental

behavior? / A. Kollmuss // Environmental Education Research. - 2002. - Vol. 8. - N. 3. - P. 239-260.

12. Кононенко О. Ю. Проекологічна поведінка населення як об’єкт суспільно-географічних досліджень /

О. Кононенко // Часопис картографії. - 2016. - Вип. 16. - С. 145-156.

13. Kurisu K. Pro-environmental behaviors / K. Kurisu. - Tokyo, Heidelberg, New York, Dordrecht and London: Springer, 2015. $-160 \mathrm{p}$.

14. Lee H. The effect of information provision on pro-environmental behaviors / H. Lee, K. Kurisu, K. Hanaki //

Low Carbon Economy. - 2015. - Vol. 6. - P. 30-40.

15. Lehman P. K. Behavior analysis and environmental protection: accomplishments and potential for more /

Philip K. Lehman, Geller E. Scott // Behavior and Social Issues. -2004. - 13. - P. 13-32.

16. Lindenberg S. Normative, gain and hedonic goal frames guiding environmental behavior / S. Lindenberg,

L. Steg // Journal of Social Issues. -2007. - 63(1). - P. 117-137.

17. Moore J. Ecological Footprints and Lifestyle Archetypes: Exploring Dimensions of Consumption and the 
Transformation Needed to Achieve Urban Sustainability / J. Moore // Sustainability. - 2015. - Vol. 7. - P. 4747-4763.

18. Наукові засади розробки стратегії сталого розвитку України: монографія. - Одеса: ІПРЕЕД НАН України, 2012. - 714 с.

19. Schwartz S. H. A normative decision-making model of altruism / S. H. Schwartz, J. A. Howard // Altruism and helping behaviour: Social, personality and developmental perspectives. - [Ed.: J. P. Rushton, R. M. Sorrentino]. Mahwah, NJ: Lawrence Erlbaum Associates, 1981. - P. 189-211.

20. Соціально-економічний потенціал сталого розвитку України та їі регіонів: національна доповідь / За ред. Е. М. Лібанової та М. А. Хвесика. - К. : ДУ ІЕПСР НАН України, 2014. - 776 с.

21. Сталий розвиток територіальної громади: управлінський аспект / Ю. О. Куц, В. В. Мамонова, О. К. Чаплигін та ін. - Х. : Вид-во ХарРI «Магістр», 2008. - 236 с.

22. Стан виконання в Україні положень «Порядку денного на XXI століття» (2002-2012) / за ред. Л. Г. Руденка. - К. : Академперіодика, 2014. - 359 с.

23. Steg L. Encouraging pro-environmental behaviour: An integrative review and research agenda / L. Steg, C. Vlek // Journal of Environmental Psychology. - 2009. - 29 (3). - P. 309-317.

24. Стратегія сталого розвитку України до 2030 року. Проект 2017 [Електронний ресурс] // UNDP [вебсайт]. - Режим доступу: http://www.ua.undp.org/content/ukraine/uk/home/library/sustainable-development-report/ Sustainable-Dev-Strategy-for-Ukraine-by-2030.html

25. Sustainable Consumption and Production Indicators for the future SDGs - UNEP Discussion Paper March 2015 [Electronic source] // Sustainable Development: Knowledge Platform [web-site]. - Access mode: https:// sustainabledevelopment.un.org/content/documents/2301SCP\%20indicators.pdf.

26. Thøgersen J. Recycling and morality. A critical review of the literature / J. Thøgersen // Environment and Behavior. - 1996, - Vol. 28 (4). - P. 536-558.

27. Уявлення населення про сталий розвиток - Аналітичний звіт за результатами національного соціологічного опитування - Березень 2017. [Електронний ресурс]: UNDP Україна [веб-сайт]. - Access mode: http://www.ua.undp.org/content/ukraine/uk/home/library/democratic_governance/report_population_perception_ sustainable_development.html. 